\title{
CSR, Local Embeddedness and the performance of MNCs in Brazil during the 2008 financial crisis
}

\author{
Henrique Correa da Cunha ${ }^{1}$, Iara Regina dos Santos Parisotto ${ }^{2}$, Andreia Carpes Dani ${ }^{3}$, \\ Vilmar Siewert 4 \\ ${ }^{1}$ Universidade Regional de Blumenau (FURB) - henriquecorreadacunha@gmail.com \\ ${ }^{2}$ Universidade Regional de Blumenau (FURB) - iaraparisotto@furb.br \\ ${ }^{3}$ Universidade Regional de Blumenau (FURB) - andreiacarpesdani@gmail.com \\ 4 Universidade Regional de Blumenau (FURB) - siewert.vilmar@outlook.com
}

\section{KEYWORDS}

Corporate Social Responsibility;

Corporate Governance;

Relational Embeddedness;

Subsidiary Performance.

Received 15.08.2017

Revised 11.10.2017

Accepted 28.11.2017

ISSN 1980-4431

Double blind review

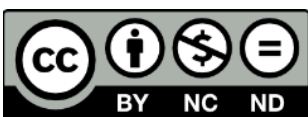

\begin{abstract}
Although the effects of the financial crisis of 2008 affected companies in several industries, not all organizations were affected in the same manner. When evaluating the implications of the 2008 financial crisis for the performance of multinational subsidiaries operating in Brazil during this period it is clear that some companies were better able to overcome the challenges imposed by the crisis. One explanation for that could be related to strategies adopted by these organizations that increase local embeddedness which in turn creates a reciprocal commitment between the company and the network in a sense that it provides a mutual support during challenging moments. In that sense, in order to relate to different stakeholders needs in foreign markets, the subsidiaries of multinational companies adopt CSR and governance practices. In order to verify the implications of CSR practices to the performance of multinational subsidiaries in Brazil during the financial crisis of 2008, the present study utilizes a panel data with 110 subsidiaries of multinational companies active in Brazil during 2008, 2009 and 2010. We perform a Pairwise Granger Causality test to confirm the causal relationship between CSR practices and performance. The results indicate that regardless of the size, there was a positive relationship between CSR and the performance of these organizations during the financial crisis of 2008.
\end{abstract}

\section{Introduction}

The performance of the multinational companies in foreign markets is affected by a condition known as the liability of foreignness (Zaheer, 1995). This condition suggests that the differences in formal and informal institutional environments between the company`s home and host country create additional challenges for foreign companies when compared to indigenous organizations.
In order to overcome such a condition, multinational companies need to identify and implement strategies that facilitate the insertion and promote the local embeddedness of subsidiaries in the foreign markets. In that sense, in order to get more involved and integrated (embedded) with the foreign markets. MNCs implement strategies that provide global integration and local responsiveness. This condition allows MNCs to take advantage of the global value chain resources at the same time as it 
is able to effectively respond to market needs and opportunities.

Deephouse and Suchman (2008) suggest that in order to attract and gain access to valuable resources in a particular market, companies need to build reputation, status which contributes for legitimating the company. Accordingly, some authors (Davies, 2003; Porter, 2006; Pearce and Doh, 2005; Porter and Kramer, 2002) indicate that companies are legitimated by their efforts related to corporate social responsibility. Therefore, Davies (2003) indicates that corporate social responsibility is a pact for mutual benefit between society that needs business for economic and social development, and business that needs a supportive business environment.

Jones, Hesterly and Borgatti (1997) suggest that although there may be no formal mechanisms that are put in place such as laws and regulations to verify the level of commitment of the company with the community, network governance forces guarantee the perpetuation of the relationships and levels of commitment. In that sense CSR in order to be legitimated needs to include governance mechanisms that promote the integration of the company with its network. In a developing country, such as Brazil, the institutional voids create a need for companies to implement governance mechanisms which limits the opportunistic behavior inside the organization and throughout the company`s business network.

The economic and financial crisis of 2008 is a good example for exploring the implications of adopting CSR and governance mechanisms for the competitiveness of organizations. At that period there was a worldwide trend that linked the lack of ethics, principles and values as being the main causes for the crisis. In that sense, Souto (2009) suggests that the lack of CSR and governance procedures were considered the main explanation for the origins of the 2008 financial crisis. As it happened in many other countries, data from Instituto Brasileiro de Geografia e Estatística (IBGE) indicate that in Brazil the effects of the global financial crisis were more severe during the years of 2008, 2009 and 2010.

Although the financial crisis of 2008 impacted many industries in several countries, not all companies were affected in the same manner. Yelkikalan and Kose (2012) indicate that complying with CSR and governance practices can impose additional challenges but also opportunities for companies during periods of economic crisis. In the same manner Jacob (2012) complements by attributing the lack of CSR practices as being one of the causes for the economic and financial crisis of 2008. Jacob (2012) also suggests that governance policies and CSR practices are actions that in addition to improving the control mechanisms and transparency of a company, these practices help organizations to overcome the challenges that arise in times of crisis.

In order to become effective when developing CSR policies, organizations must redefine business objectives addressing stakeholders` needs and include these concerns in the company's strategy. The change in attitude and perspective should be the result of a reflection on the core value of the company, which will be favored by positive effects on internal variables, such as motivation and corporate culture; the support of stakeholders; strengthening of business strategy; strengthening the market position of the company; investor confidence; and compliance of business processes with corporate governance policies. Considering these elements, companies that adopt governance practices and CSR will be in an advantageous position to overcome financial crises affecting the market in which they operate. In this sense CSR should be perceived as a business opportunity and not a cost (Souto, 2009).

Given the above, the present study has the following objective: To determine whether there is relationship between corporate social responsibility (CSR) and performance of subsidiaries of multinational companies active in Brazil during the crisis of 2008.

Then, we seek to answer the following research question: Is there a positive relationship between corporate social responsibility and performance of subsidiaries of multinational companies operating in Brazil during the 2008 financial crisis?

In that sense, it is suggested that during periods of economic and financial crisis, the subsidiaries of multinational companies operating in Brazil who practice and communicate their efforts related to governance and CSR initiatives should have superior performance when compared to companies that do not have these initiatives. This condition should validate the hypothesis that by implementing CSR, companies are rewarded by a reciprocal commitment relationship between the company and its stakeholders.

Revista de Negócios, v. 21, n. 3-4, p. 25-38, July, 2016. 
This study intends to contribute for increasing the knowledge regarding the implications of CSR to the performance of multinational subsidiaries operating in Brazil during the financial crisis of 2008. In that sense, the results could indicate that implementing CSR initiatives could be a viable strategy that helps foreign companies to get better integrated (embedded) with foreign markets.

\section{Theoretical Framework and Hypothesis}

2.1 CSR and the Financial Crisis of 2008

Nowadays identifying the elements that determine the competitiveness of organizations becomes a huge challenge due to the complexity of environments in which organizations operate. Globalization creates opportunities related to strategic location of resources which promote synergy of organizational resources but it also increases the complexity related to the control mechanisms needed to coordinate and monitor the performance of each activity in the organization value chain. In this complex scenario, companies need to balance the opportunities of locating resources in global value chains with the particular needs of the markets serviced by the company.

In this fast changing business environment, the role of organizations have changed dramatically, in addition, recent financial scandals and the collapse of large corporations, the attention given to CSR has grown significantly (Karaibrahimoglu, 2011). Scott (1995) identifies three dimensions (pillars) of the institutional environment of a country that imply the quality and safety related to the control mechanisms and governance procedures of these regions. In that sense, Scott (1995) indicates that the regulatory pillar represents the quality of the laws and regulations and to what extent these rules are monitored and enforced. The cognitive pillar relates to the cultural and shared values embedded in the society, that is, how people understand and relate to things. The normative pillar refers to beliefs and values which create expectations regarding the behavior of the individuals in the society.

Deephouse and Suchman (2008) suggest that the reputation, status and legitimacy facilitate the access to scarce and valuable resources. This condition relating to the institutional environment of a country, it is clear that countries with a more stable environment and more developed institutionally favors attracting foreign investment. In the same sense, companies with better governance and more committed to the local markets may gain facilitated access to valuable and scarce resources.

The global financial crisis led to economic recession in various countries around the world. All companies, including multinational companies were forced to cut spending including expenses related to the corporate social responsibility practices (Njoroge, 2009). Although in times of economic and financial crisis these practices are rational, as indicated by Carroll (1996), during economic crisis, priority becomes the financial responsibility of the organization. The same author indicates that reducing commitment to CSR can signal to the various stakeholders a vulnerable situation and the possibility of a collapse. It is also argued that during a financial crisis, the positioning of organizations becomes more conservative focusing on what it essential. In that sense, many companies perceive CSR initiatives as not being a crucial activity during these periods (Cheney et al., 1990; Karaibrahimoglu, 2011).

As far as it concerns the financial crisis of 2008, it can be said that the global crisis was a result of the North American real estate crisis which also reflected in European countries. As mentioned earlier, in Brazil, according to IBGE (2014), the effects of the global financial crisis of 2008 impacted the economy during the period from 2008 to 2010. Brazil was impacted because of its strong dependence on the export of agricultural and mineral commodities.

In Brazil the statement made in October 2008 by president Luiz Inacio Lula da Silva, that the crisis in Brazil was only a "wake". At the time the president did not recognize the implications of the crisis in the developed countries which reflected in lower consumption of commodities produced in the country, which consequently impacted negatively various sectors of the Brazilian economy.

To examine how the global financial crisis affects corporate social responsibilities of multinational companies in Kenya, Njoroge (2009) found that there was a negative influence of the crisis on corporate responsibility of companies, which include, for example, the postponement or cancellation of social projects. Similarly to that, Karaibrahimoglu (2011) when analyzing the 100 companies listed in Fortune magazine, found that

Revista de Negócios, v. 21, n. 3-4, p. 25-38, July, 2016. 
there is a significant decrease in numbers and extent of CSR projects in times of financial crisis.

Jacob (2012) sought to analyze the impact of the financial crisis of 2008 on Corporate Social Responsibility initiatives and their implications for the reputation risk management of the companies during a period of crisis. The results showed that the 2008 financial crisis had a clear impact on CSR initiatives in many companies, due to the struggle to survive, which also related to mass layoffs and spending cuts in programs with community involvement.

However, some efforts related to CSR gained greater attention after the crisis, such as governance, organizational environmental policies, and compensation policies. Key stakeholders who had been affected by the crisis were involved, followed by investors and customers putting additional pressure for the company to adopt better governance and CSR policies. Miras and Carrasco (2013) argue that these circumstances make it possible to verify the true motivations or interests of carrying out social or environmental policies for businesses and offer a perfect opportunity to test the real commitment of companies to CSR. If companies implement CSR actions seeking legitimacy or direct benefits (short-term view), the CSR should be drastically affected by the crisis. In that sense, organizations that are really committed to CSR and have it integrated to their business strategy, they could take advantage of the crisis as an opportunity rather than considering it as a threat. Therefore, the present crisis cannot directly mean the disappearance of CSR actions, though it can influence the reduction of the number of these initiatives (Miras and Carrasco, 2013).

CSR activities are important for overcoming some social problems caused by the crisis. Davies (2003) indicates that it is possible to propose that CSR can produce useful results for both the organization and for the society. Engaging in CSR activities could be a good way of identifying opportunities created by the crisis to increase the company involvement with its stakeholders (Yelkikalan and Kose, 2012). Therefore Yelkikalan and Kose (2012) presented in Figure 1, the impact of the crisis on CSR.
Figure 1. The impact of crisis to CSR

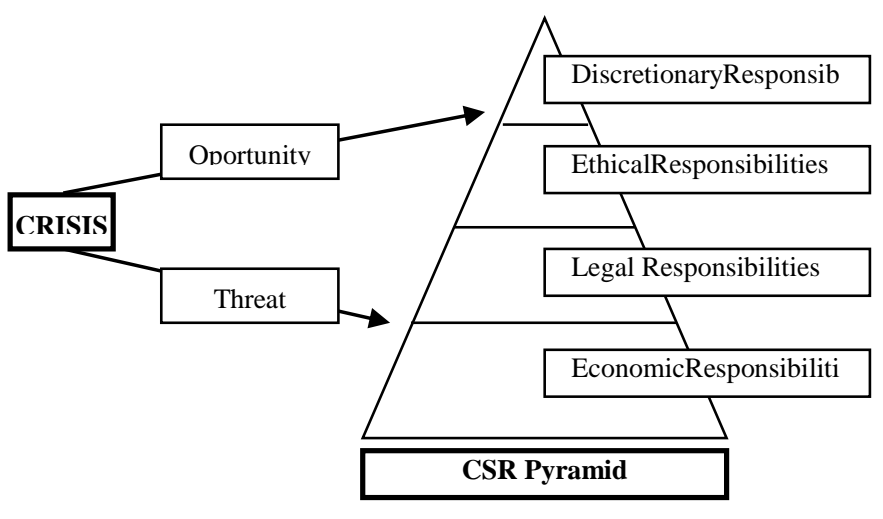

Source: Yelkikalan e Kose (2012).

The model presented in Figure 1 builds upon Carroll (1991) CSR Pyramid and seeks to explain the effects of an economic crisis to CSR under different perspectives (opportunities and threats). It suggests that the organizations commitment to CSR practices during periods of economic crisis will depend on the dimensions of CSR and the priority of such initiatives. Thus, economic crisis poses a threat to the responsibility dimensions located on the top of the pyramid, that is, for the CSR.

Yelkikalan and Kose (2012) indicate that large companies continue their CSR activities without interruption, even in times of economic crisis, supporting various social and artistic activities. The dilemma that "the crisis has a positive or negative effect on social responsibility activities" must be analyzed from the standpoint of the pyramid components, as there may be different impacts for each element. Such a perspective might be useful for understanding the behavior of companies who see the crisis as a threat to their economic activities and take precautions, but at the same time remain their CSR activities without interruption in times of crisis.

\subsection{Institutional Theory, Legitimation and Local Embeddedness}

The hierarchy suggested in Carroll (1991) CSR Pyramid highlights the prioritization of the needs of for-profit organizations. The pyramid indicates that the basic condition for promoting the competitiveness and perpetuation of the business is to meet the economic objectives and expectations the stockholders (investors) have for the business. These goals must be achieved respecting the

Revista de Negócios, v. 21, n. 3-4, p. 25-38, July, 2016. 
regulatory requirements imposed by the formal institutional environment (Scott, 1995) in which the company operates. After meeting these basic criteria, the organization may proceed to the higher stages of the pyramid in which CSR initiatives take place.

Although the hierarchy pyramid of corporate responsibilities of Carroll (1991) suggests that meeting the economic and legal responsibilities are premises to promote the other responsibilities, Deephouse and Suchman (2008) indicate that ethical and voluntary responsibilities contribute to the creation of status and reputation which are needed to legitimate the organizations. Deephouse and Suchman (2008) argue that legitimated organizations are more competitive because they address the needs of a broader range of stakeholders which in turn support these companies.

In this sense, the institutional theory indicates that organizations are socially rewarded for their legitimacy by gaining access to valuable and scarce resources (Deephouse and Suchman, 2008). The same authors indicate that these elements promote the perpetuation of organizations who conform are better able to adapt the coercive, normative and cognitive forces of the market in which they operate (DiMaggio \& Powell, 1991; Meyer and Rowan, 1991).

Meyer and Rowan (1977) present the legitimacy as being an organization valuable resource ranked in the same level as tangible assets suggesting that this feature is crucial to promote the competitiveness of an organization. The same authors indicate that organizational performance depends not only on efficient use of resources, but also compliance with the institutionalized myths in the organizational environment.

Both the compliance of the organization with society's expectations and the discipline to demonstrate a rational behavior contribute for creating a good reputation for the organization. In the business context, it is argued that reputation is a widespread expectation of the company's future performance based on collective perceptions of past behavior and performance (Ferguson, Deephouse, Ferguson 2000; Fombrun, Rindova, 1996).

In the new institutional theory, Deephouse and Suchman (2008) indicate that status is a central element for the competitiveness of organizations. Status is a social construct which involves the ordering or the classification of social actors (Washington and Zajac, 2005: 284) based on the rank that each may possess depending on the membership to a group or groups of practices, values, characteristics and different capabilities that distinguish the individuals (Benjamin and Podolny, 1999; Weber, 1946).

In that sense, the new institutional theory suggests that reputation, status and legitimation enable companies to gain access to valuable and scarce resources on the market. In that sense, legitimation should be regarded as a strategic effort since it can involve the differentiation (possession and control of a unique resource) or isomorphic (adaptation and compliance with regulations and industry standards).

Deephouse and Suchman (2008) present the model in Figure 2 which suggests the competitive advantages generated by status, reputation and legitimation of organizations.

Figure 2. Status, reputation and legitimation and flow of resources

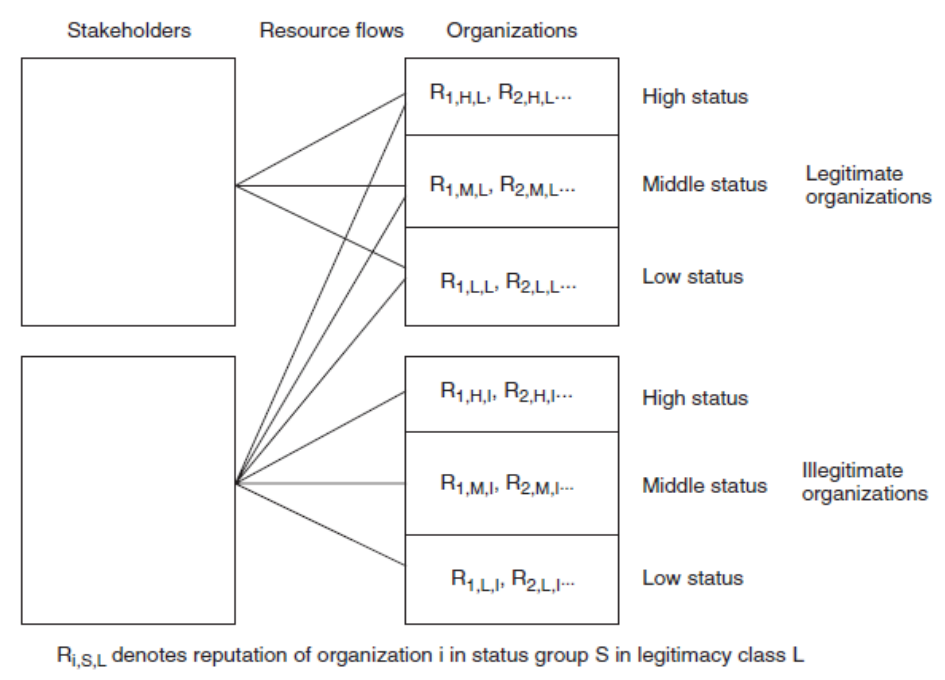

Source: Deephouse and Suchman (2008).

The model proposed by Deephouse and Suchman (2008) indicates a dynamic and interactive process between organizations and different stakeholders groups (communities, governments, customers, suppliers and markets). It indicates that reputation, legitimacy and status are decisive factors for the organization to gain access to resources from specific groups of stakeholders. Examples of this interaction include organizations seeking legitimacy through certification, social activities and other types of initiatives that increase or favor the acceptance of the organizations for specific groups of stakeholders.

Revista de Negócios, v. 21, n. 3-4, p. 25-38, July, 2016. 
In this context, Meyer and Rowan (1977) present the symbolic meaning of institutionalization. For Meyer and Rowan (1977), the leaders of the organizations have a decisive role in committing the organization's efforts and resources, both internally and externally, to communicate the mission of the organization which should include the interests of different stakeholders. In that sense, legitimacy is created through communicating the company's values and mission for the company`s employees, customers, suppliers, government and community in which the company operates. Therefore, many companies provide Corporate Governance and Social Responsibility reports that intend to legitimate and communicate internally and externally these initiatives.

Similarly to that, DiMaggio and Powell (1983) suggest that institutional legitimacy increases the chances of businesses survival due to the greater acceptance of these organizations in the markets they operate. When considering the scope of CSR initiatives, Logsdon and Wood (2002) indicate that companies can address global or local issues. By adopting CSR initiatives that address local community and market concerns organizations are rewarded by local support. This condition favors organizations that adopt CSR practices as these initiatives create competitive advantage (Kilkenny, Nalbarte and Besser, 1999).

Another important consideration related to addressing stakeholders' needs is that it may contribute for the local embeddedness of the multinational subsidiary in the foreign country. In the MNC context, local embeddedness could be described as a condition in which the subsidiary develops ties in the foreign country (Polanyi, 1944). This condition, according to Hansen (1999) and Schulz (2003) facilitate the knowledge sharing among the network in which the organization operates.

The concept of embeddedness was introduced by Karl Polanyi in 1944 in his book The Great Transformation. Several years later in 1985 Mark Granovetter made a significant contribution to the embeddedness concept in his essay titled "Economic Action and Social Structure: The Problem of Embeddedness".

Although Gimeno, Baum and Dutton (1996) indicate that in an economic setting, individuals will act in a manner that maximizes utility or profit of a transaction, Granovetter (1985) indicates that the embeddedness concept complements and further explains the dynamics of competitive markets. Uzzi $(1996,1997)$ for instance, separates market transactions into two different categories which are the arm`s length and the embedded interorganizational ties. For the arm`s length transaction, Uzzi (1996, 1997) highlights the impersonal, diffuse and volatile (shifting) membership relationships among organizations. This condition favors for opportunistic behavior and increases the costs associated with communications and monitoring the partner's actions in the business chain. Uzzi (1996, 1997) indicates that firm embeddedness creates value to organizations and markets in three different ways: it builds trust among the members, it improves the quality and facilitates the sharing of information, and embedded companies engage in mutual collaboration which includes problem solving and supporting each other.

According to Kilkenny, Nalbarte and Besser (1999), by adopting governance and CSR practices' focused on local needs, MNCs get more involved with the specific demands and opportunities of the foreign market. By including these initiatives in the strategic planning of a multinational organization, the result could lead to an increased embeddedness of the subsidiary with the foreign market. This condition could represent an important element for companies to overcome the liability of foreigners.

In this sense, the literature review indicates that companies that address and communicate their efforts related to corporate governance and corporate social responsibility should be rewarded for such initiatives. Companies that continue their commitment to local CSR even during periods of financial crisis should have the benefit of a reciprocal commitment from the market which should support the company during these difficult moments. Therefore, in order to verify if companies that promote CSR have superior performance during the financial crisis of 2008 we present the following hypothesis:

H1: Foreign subsidiaries in Brazil with CSR initiatives have superior performance during the financial crisis of 2008 .

\subsection{Size and Performance}

The differences in political, social and Revista de Negócios, v. 21, n. 3-4, p. 25-38, July, 2016. 
economic environments generate an enormous diversity in the conditions in which organizations develop and operate. The organizational ecology presented by Hannan and Freeman $(1977,1984)$ attempts to explain the abundance of organizational models and structures in the light of these elements and present explanations for the changes suffered by organizations over the years. In order to further explore the implications of political, social and economic conditions and changes to the organizations, Hannan and Freeman $(1977,1984)$ introduce the concept of organizational inertia as a condition that creates resistance to change in organizations which are already operating. Therefore large firms could be less affected or take longer to respond to external conditions while the smaller firms should respond faster.

Freeman et al. (1983) also recommended that the organizations' failure rates decline as these entities get bigger. Hannan and Freeman (1984) suggest that increasing the company's size allows it to gain access to distinct and more competitive resources. These include more experienced and better trained human resources, more competitive suppliers and inputs and superior technology.

Favaro, Bomberger and Meer (2009) evaluate the indicators and the conditions faced by companies during periods of financial crises. Favaro, Bomberger and Meer (2009) indicate that one of the first effects of a financial crisis is the drop in sales volumes for the companies. The same authors suggest that when there is a drop in sales volumes, companies immediately search for opportunities to cut down costs. In their struggle to survive, many companies make mistakes (wrong decisions) by eliminating activities which are not only desired but are necessary to meet the demands and the expectations of its stakeholders.

During periods of economic crisis, when sales decline, companies cut down costs which in many cases include CSR initiatives. Favaro, Bomberger and Meer (2009) indicate that these actions rather than contributing to the company's recovery, cause an ever greater decline in revenues as a consequence of the reciprocal response from the market. These findings confirm what Deephouse and Suchman (2008) indicate, which suggests that the loss of legitimacy makes the organization to lose the support of different groups of stakeholders.

When evaluating the relationship between company size and its commitment to CSR even during periods of economic crisis, Yelkikalan and Kose (2012) indicate that larger companies tend to continue their CSR efforts even during these challenging moments. In that sense, Freeman et al. (1983) indicate that the failure rates decline with the greater size of the organizations.

In order to evaluate the implications of company size to the performance of the subsidiaries of multinational organizations operating in Brazil during the financial crises of 2008, we present the following hypothesis:

$\mathrm{H} 2$ : There is a positive relationship between size and the performance of MNCs subsidiaries in Brazil during the financial crisis of 2008.

\subsection{Similar Studies}

Although several studies (Simionescu and Dumitrescu, 2014; Miura, Marcon and Souza, 2011; Giannarakis and Theotokas, 2011; Freguete, Nossa and Funchal, 2015) attempted to analyze the relationship between CSR and the performance of organizations, there are still no conclusive results about this condition.

Simionescu and Dumitrescu (2014) analyzed 81 Romanian companies listed on the Bucharest Stock Exchange (BSE) in order to determine whether CSR practices can be related to the financial performance during the economic recession, between 2006 and 2012 . The results suggest a positive relationship between CSR practices and financial performance of companies. Simionescu and Dumitrescu (2014) suggest that CSR practices generate benefits for the business in the long term, leading to a competitive advantage and create new opportunities for these organizations.

Miura, Marcon and Souza (2011) analyzed the average profitability of the Corporate Sustainability Index (ISE) and compared it to the Bovespa Index (Ibovespa) in the period from January 2008 to December 2010 which was characterized by the global financial crisis of 2008 . Miura, Marcon and Souza (2011) found no statistically significant difference between the average daily return of the ISE and the Ibovespa, even in times of crisis that occurred in 2008. Therefore, companies listed on the ISE did not offer different returns to shareholders when compared to those that do not take CSR initiatives

Revista de Negócios, v. 21, n. 3-4, p. 25-38, July, 2016. 
as part of their strategies. This could be an indication that CSR does not contribute for superior performance during periods of economic crisis, but it also suggests that CSR does not hinder the competitiveness of these organizations.

Likewise, Giannarakis and Theotokas (2011) evaluated the effect of the financial crisis on corporate social responsibility performance (CSR). Giannarakis and Theotokas (2011) analyzed 112 companies included in the GRI report list in 2007, 2008, 2009 and 2010. The results indicate a better CSR performance before and during the financial crisis, except for the period 2009 and 2010. This could be an indication that in order to retain their legitimacy and community support, these companies remained committed to their CSR initiatives even during the difficult times of economic crisis.

Freguete, Nossa and Funchal (2015) analyzed the relationship between the practice of corporate social responsibility and financial performance of Brazilian companies during a period of financial crisis of 2008. The results indicate that during crises, socially responsible firms do not have a differential financial performance compared to other firms in the market. Although the study did not identify a statistically significant relationship between CSR and performance, it demonstrates a significant effect of the 2008 crisis for the Brazilian economy.

\section{Methodology and Data}

For the present study, it was employed the list of multinational subsidiaries included in the 500Maiores e Melhoresfrom the Exame magazine. Although theExame magazine database has cataloged over 2,000 companies, for the present study, we selected subsidiaries of foreign multinational companies operating in Brazil during the period from 2008 and 2010 which was the most affected by the global financial crisis of 2008. By employing these criteria, there were data available for 110 subsidiaries of multinational companies active in Brazil during 2008, 2009 and 2010. This resulted in a total of 330 observations.

The data related to the financial performance of the multinational subsidiaries were collected from Exame magazine website. The CSR variable, which for the present study represents an independent variable, was collected from the sustainability reports published in the company`s websites.

Favaro, Bomberger and Meer (2009) recommend that in times of crisis one of the first indicators that signal the fall of performance in organizations is related to the volume of sales. In that sense, the performance of the subsidiaries will be measure regarding its sales change during the period. In order to verify the adequacy of using sales change as a performance indicator, for the present study it was included productivity measurement variables such as export as a percentage of sales and sales per employee. These variables were included in the panel data model in order to verify if they help explaining the change in sales during the period.

Table 1. Variables description

\begin{tabular}{|c|c|c|}
\hline $\begin{array}{c}\text { Analysis } \\
\text { Criteria } \\
\end{array}$ & Variable & Description \\
\hline Performance & $\begin{array}{l}\text { Sales } \\
\text { change }\end{array}$ & Sales change. \\
\hline \multirow{2}{*}{ Productivity } & $\begin{array}{l}\text { Sales by } \\
\text { Employee }\end{array}$ & $\begin{array}{l}\text { Sales divided by the number } \\
\text { of employees. }\end{array}$ \\
\hline & $\begin{array}{c}\text { Export } \\
\text { over Sales }\end{array}$ & $\begin{array}{l}\text { Export as a proportion of } \\
\text { total sales. }\end{array}$ \\
\hline \multirow[b]{2}{*}{ Size } & Employees & Number of Employees. \\
\hline & $\begin{array}{c}\text { Total } \\
\text { Equity }\end{array}$ & Total stockholders`equity. \\
\hline CSR & $\begin{array}{c}\text { CSR } \\
\text { Report }\end{array}$ & $\begin{array}{l}\text { Dummy indicating the } \\
\text { existence of a Governance } \\
\text { and Sustainability Report } \\
\text { provided on the subsidiary } \\
\text { website (coded as } 1 \text { when } \\
\text { CSR report is available and } \\
0 \text { when not). }\end{array}$ \\
\hline
\end{tabular}

Source: Elaborated by authors.

In order to better analyze the relationship between CSR and the performance of multinational companies in Brazil during the three years comprised by the present study, data for the CSR dummy variable were attributed for each year of the period. It is important to note that in many cases, companies did not provide CSR reports throughout the period.

\section{Pairwise Granger Causality Test}

In order to verify the causal relationship between CSR practices and the performance of foreign multinational subsidiaries operating in Brazil during the period from 2008 to 2010 we performed a Pairwise Granger Causality test. Granger (1969) presented a methodology for testing the causal relationship between variables.

Revista de Negócios, v. 21, n. 3-4, p. 25-38, July, 2016. 
The approach intends to answer the question of whether $\mathrm{X}$ causes $\mathrm{Y}$ and how much of the present value of $\mathrm{Y}$ can be explained by past values of $\mathrm{X}$. By performing the Granger causality test it is possible to verify not only the causal relation between the variables but also by testing the implications of different lags to the relationship it allows a deeper analysis in terms of how long does it takes (in terms time periods) for $\mathrm{Y}$ to affect $\mathrm{X}$.

\section{Panel Data Model}

The analysis performed in this study employed the panel data model which according to Raj and Baltagi (1992) combines cross-sections with time series. This method permits to evaluate the relationship between several variables by following the same individuals throughout a time period.

Wooldridge (2006) recommends that a panel data model can be described by Equation 1. This equation suggests that yit is the dependent variable, $\beta 0$ is the intercept, $\beta x i t$ is the dependent variable, aij are unobserved factors that are fixed over time, while uit is the residual error, this can change over time. It also realizes that $i$ is the $i$-th component of the cross-section while $t$ represents the $t$-th time period contemplated in this period.

Equation 1. Panel data equation

$$
y i t=6 o+b x i t+\alpha i+u i t, t=1,2, \ldots, T, i=1,2, \ldots, I
$$

Source: Wooldridge (2006).

The panel data tests will be performed with the EViews software which will test the hypotheses presented for this study.

\section{Analysis}

In order to test the causal relationship between CSR practices and the performance measured in terms of sales change during the 3 years period we performed the Pairwise Granger Causality test using EViews. The results for the Pairwise Granger Causality tests for verifying the implications of 1 time period lag are presented in Tables 2.

Table 2. Pairwise Granger Causality Test for 1 time lag

\begin{tabular}{cccc}
$\begin{array}{c}\text { Sample: } 20082010 \\
\text { Lags: } 1\end{array}$ & & \\
\hline \hline Null Hypothesis: & Obs & F-Statistic & Prob. \\
\hline \hline CSRReport does not Granger Cause Sales & & & \\
Change & 220 & 2.81910 & 0.0946 \\
Sales Change does not Granger Cause CSRReport & 0.12238 & 0.7268 \\
\hline \hline
\end{tabular}

Source: Survey data.

Table 3 presented next, provides the test results for the Pairwise Granger Causality tests using 2 time period lags.

Table 3. Pairwise Granger Causality Test for 2 time lags

Sample: 20082010

Lags: 2

\begin{tabular}{llll}
\hline \hline Null Hypothesis: & Obs & F-Statistic & Prob. \\
\hline \hline CSRReport does not Granger Cause Sales & & \\
Change & 110 & 1.48820 & 0.2305 \\
Sales Change does not Granger Cause CSRReport & 0.05718 & 0.9445 \\
\hline
\end{tabular}

Source: Survey data.

The results from Table 2 which test the implications of CSR practices to Sales Change during the 2008 to 2010 period indicate that at the $90 \%$ confidence level, we would reject the Null Hypothesis that CSR Practices does not Granger Cause Sales Change. Additionally the results from the same table indicate that there is a probability of $72 \%$ that Sales Change does not Granger Cause CSR practices. These results are a strong indication that CSR practices support sales growth during the period.

In order to further explore the implications of different time lags on the relationship between CSR practices and the performance of foreign subsidiaries in Brazil during the period from 2008 to 2010 we present in Table 3 the results for the Pairwise Granger Causality test using 2 time lags. By comparing the results from Table 2 and Table 3 it is clear that the effects of X (CSR practices) on $\mathrm{Y}$ (Performance) happen in a short term. The results indicate that companies that changed their CSR practices by either adopting or dropping these initiatives will face the consequences in terms of sales change in the subsequent period.

Table 4 presents the results obtained for the panel data model used to test the hypotheses proposed for the present study. First we performed a Hausman test in order to verify the best suited estimator. The Hausman test indicated that Fixed

Revista de Negócios, v. 21, n. 3-4, p. 25-38, July, 2016. 
Effects to be the adequate estimator for our model.

The sample has 110 subsidiaries of multinational companies operating in Brazil from 2008, 2009 and 2010. The period was chosen to assess whether MNCs operating in Brazil with CSR practices outperform the ones that do not have such initiatives during the 2008 global financial crisis. It was also verified the implications for hypothesis 2 which suggests that size has a positive relationship with performance.

Table 4. Panel data model results

\begin{tabular}{|l|c|c|c|c|}
\hline \multicolumn{1}{|l|}{} & Coeffic. & Std. Error & t-ratio & p-value \\
\hline const & -95.144 & 19.025 & -5.0009 & $<0.0001$ \\
\hline CSRReport & 27.7404 & 7.4047 & 3.7463 & 0.0005 \\
\hline Employees & 0.00041 & 0.00026 & 1.5568 & 0.1267 \\
\hline Total Equity & 0.01491 & 0.01330 & 1.1213 & 0.2683 \\
\hline Sales byEmployee & 0.1114 & 0.03291 & 3.3850 & 0.0015 \\
\hline Ebitda & 0.0281 & 0.01168 & 2.4100 & 0.0202 \\
\hline Export over Sales & 2.494 & 0.65724 & 3.7949 & 0.0004 \\
\hline & & & \\
\hline Mean dependvar & 0.069072 & S.D. depend var & 18.1142 \\
\hline Sum squaredresid & 8033.807 & S.E. ofregression & 13.5124 \\
\hline LSDV R-squared & 0.744959 & Within R-squared & 0.56577 \\
\hline LSDV F(52, 44) & 2.471564 & P-value(F) & 0.00129 \\
\hline Log-likelihood & -351.847 & Akaikecriterion & 809.694 \\
\hline Schwarz criterion & 946.1539 & Hannan-Quinn & 864.871 \\
\hline Rho & -0.57643 & Durbin-Watson & 2.11880 \\
\hline Source: Survey & & \multicolumn{5}{|l|}{} \\
\hline
\end{tabular}

Source: Survey data.

Additionally, in order to verify collinearity issues in the proposed model we performed a Variance Inflation Factor (VIF) test for the variables included in the model presented in Table 4. The results for the VIF tests are presented in Table 5.

Table 5. VIF test results

Variance Inflation Factors

Date: 05/25/17 Time: 11:13

Sample: 20082010

\begin{tabular}{lll}
\hline \hline \multicolumn{1}{c}{ Variable } & $\begin{array}{c}\text { Coefficient } \\
\text { Variance }\end{array}$ & $\begin{array}{c}\text { Centered } \\
\text { VIF }\end{array}$ \\
\hline \hline $\mathrm{C}$ & 411.5218 & $\mathrm{NA}$ \\
CSRReport & 68.95559 & 1.272800 \\
Employees & $9.18 \mathrm{E}-08$ & 1.126022 \\
Total Equity & 0.000185 & 1.138363 \\
Sales by Employee & 0.001004 & 1.030165 \\
Export over Sales & 0.535386 & 1.036110 \\
\hline \hline
\end{tabular}

Source: Survey data.
In order to test for multicollinearity, we present in Table 5 the results for the variance inflation index (VIF) that shows values below 1.3 which is much lower than the maximum value of 10.0 recommended by Neter, Wassrmann and Kutner (1990).

The panel data model tests results presented in Table 4 shows the relationship between the dependent variable which measures the sales change for the companies during the period and the independent variables. The results indicate a positive and statistically significant relationship between sales change and the CSR. This results support hypothesis 1 which recommends that the CSR efforts of organizations contribute for the superior performance of multinational subsidiaries operating in Brazil during the financial crisis of 2008.

These findings may also confirm the benefits generated by being embedded in the market as indicated by Uzzi (1996, 1997). The author suggests that companies embedded in their value chains develop ties which build trust among the members who collaborate to find mutually benefiting strategies to overcome challenging moments. The members of these informal market structures understand that in order to sustain the competitiveness and the attractiveness of the market it is important not only to compete but cooperate with customers, suppliers, and other business partners (Nalebuff and Brandenburger, 1995). In that sense, foreign subsidiaries that implement CSR may have the benefit of network cooperation during economic crises which reduces the effects of the crisis to these organizations.

The results also indicate that size, measured by the number of employees and total stockholders' equity did not present a statistically significant relationship with the sales change during the period. These results suggest that regardless of the size of the organizations, corporate social responsibility has a positive relationship with the performance of multinational companies subsidiaries operating in Brazil during the financial crisis of 2008. Although Hannan and Freeman (1984) indicate that larger companies have access to superior and more competitive resources, and that this condition lead to superior performance, the results from the present study indicate that the CSR relationship with performance occur independent of the organization size. This condition refutes hypothesis 2 and suggests that CSR leads to

Revista de Negócios, v. 21, n. 3-4, p. 25-38, July, 2016. 
superior performance of multinational subsidiaries during periods of crisis regardless of the size of the organization.

The findings suggest that companies that have concerns about CSR and corporate governance may have superior management processes and practices that contribute for the superior performance of these organizations. Also according Deephouse and Suchman (2008), we can conclude that companies that promote CSR practices and maintain these efforts during periods of economic crisis have advantages related to access to specific resource and the support of different groups of stakeholders. Deephouse and Suchman (2008) suggest that among these stakeholders are customers and suppliers that remain loyal to these organizations (which have legitimacy) during times of crisis.

The results indicate that by adopting CSR practices that address the local market needs, these organizations may be able to increase their local embeddedness by creating stronger and reciprocal commitment relationships in the Brazilian market. According to Hansen (1999) and Schulz (2003) local embeddedness facilitates the knowledge sharing among the network in which the organization operates. This condition, when applied to the additional challenges faced by multinational companies in a foreign market, may explain how the adoption of CSR which contributes for the local embeddedness of foreign subsidiaries can lead to superior capacity for overcoming the liability of foreignness (Zaheer, 1995).

\section{Conclusion}

The present study indicates a positive relationship between CSR practices and the performance of multinational subsidiaries in Brazil. Although the present study does not investigate the peculiarities of the CSR initiatives adopted by the foreign subsidiaries in Brazil, the results indicate that regardless of company size, organizations that adopt CSR practices had superior performance during the financial crisis of 2008. This may indicate that companies that promote CSR addressing the needs of different groups of stakeholders may have the benefit of a reciprocal commitment from these parties.

The results could also be an indication that CSR practices adopted by foreign multinationals in
Brazil contribute not only for overcoming the liability of foreignness but also for fulfilling the institutional voids found in Brazil. The results could also indicate that the increased commitment of foreign subsidiaries who adopt CSR practices in Brazil lead to greater embeddedness of these organizations. This condition, as suggested by Uzzi $(1996,1997)$ may build trust and facilitate the flow of information and the communication between these organizations and the foreign market.

Another important contribution of this project relates to the results from the causality tests which indicate that the changes in CSR practices affect the performance in subsequent period. Being aware of this condition is important for companies operating in Brazil in a sense that adopting or dropping CSR practices should have implications to the change in sales in the subsequent period.

Findings from the present study support the recommendations of Kanter (2011) which indicates that companies that promote corporate social responsibility activities to meet demands of society and its employees are rewarded by these initiatives. Kanter (2011) suggests that CSR practices bring positive results for organizations, because in order to become socially responsible, these organizations need to adopt management practices that contribute for the superior financial performance of these organizations.

These findings also bring interesting insights related to the importance of including global and local concerns into the strategic planning of MNCs. The results from the present study also indicate that the export intensity proved to have a positive relation with maintaining sales volumes during the crisis of 2008. This could indicate an important characteristic for the role of subsidiaries which are capable not only of servicing the domestic market in a competitive manner, but also to dispose any excess capacity through the MNCs global value chains.

In that sense, the ability of sustaining sales and production volumes are an important consideration regarding capacity planning and the competitiveness of the organizations. Favaro, Bomberger and Meer (2009) indicate that maintaining the levels (volume) of sales is a constant concern, since the cost structure and competitiveness of an organization is determined on the basis of these volumes (minimum efficient scale).

Although the value of CSR reporting may be

Revista de Negócios, v. 21, n. 3-4, p. 25-38, July, 2016. 
constantly challenged and put into question, the present study demonstrates that subsidiaries of foreign companies that are committed to these initiatives have superior performance. In that sense, Kanter (2011) recommends that companies that perform and communicate effectively their efforts related to CSR gain a prominent leadership position and that contributes to the perpetuity of these organizations in the market.

The findings from the present study could be further explored by evaluating the characteristics of CSR adopted by these companies and how these initiatives promote local embeddedness of the foreign subsidiaries in the Brazilian market. Identifying the peculiarities of the CSR initiatives adopted by these organizations could be an important contribution for evaluating how these MNCs are addressing different stakeholders needs in Brazil and how this could lead to greater embeddedness of these organizations explaining the superior performance of corporate social responsible organizations.

\section{References}

Brandenburger, A. M., \&Nalebuff, B. J. (1995). The right game: Use game theory to shape strategy. Harvard business review, 73(4), 57-71.

Carroll, A. B. (2000). Ethical challenges for business in the new millennium: Corporate social responsibility and models of management morality. Business Ethics Quarterly, 10(01), 33-42.

Cheney, G., \& McMillan, J. J. (1990). Organizational rhetoric and the practice of criticism. Journal of Applied Communication Research, 18(2), 93-114.

Choi, J. S., Kwak, Y. M., \&Choe, C. (2010). Corporate social responsibility and corporate financial performance: Evidence from Korea. Australian Journal of Management, 35(3), 291-311.

Davies, R. (2003), "The business community: Social responsibility and corporate values", in Dunning, J.H. (Ed.), Making Globalisation Good The Moral Challenges of Global Capitalism, Oxford University Press, New York, NY.

Deephouse, D. L., \&Suchman, M.
(2008).Legitimacy in organizational institutionalism. The Sage handbook of organizational institutionalism, 49, 77.

DiMaggio, P. J., \& Powell, W. W. (Eds.). (1991). The new institutionalism in organizational analysis (Vol. 17). Chicago, IL: University of Chicago Press.

Favaro, K., Bomberger, T., \& Meer, D. (2009). Five rules for retailing in a recession. Harvard Business Review, 87(4), 64-72.

Freguete, L. M., Nossa, V., \& Funchal, B. (2015).Corporate social responsibility and Brazilian firms' financial performance. Revista de AdministraçãoContemporânea, 19(2), 232-248.

Giannarakis, G., \&Theotokas, I. (2011).The effect of financial crisis in corporate social responsibility performance. International Journal of Marketing Studies, 3(1), p2.

Gimeno, J., Woo, C. Y., Baum, J. A., Dutton, J. E., Greenwich, C. T., \& Press, J. A. I. (1996). Economic Multiplexity: The Structural Embeddedness Of Cooperation. Advances in strategic management, 13, 323-361.

Granger, C. W. (1969).Investigating causal relations by econometric models and cross-spectral methods.Econometrica, 37(3):424-438.

Granovetter, M. (1985). Economic action and social structure: the problem of embeddedness. American journal of sociology, 481-510.

Hannan, M. T., \& Freeman, J. (1984).Structural inertia and organizational change. American sociological review, 149-164.

Hansen, M. T. (1999). The search-transfer problem: The role of weak ties in sharing knowledge across organization subunits. Administrative science quarterly, 44(1), 82-111.

Jacob, C. K. (2012). The impact of financial crisis on corporate social responsibility and its implications for reputation risk management. Journal of Management and Revista de Negócios, v. 21, n. 3-4, p. 25-38, July, 2016. 
Sustainability, 2(2), p259.

Jones, C., Hesterly, W. S., \&Borgatti, S. P. (1997). A general theory of network governance: Exchange conditions and social mechanisms. Academy of management review, 22(4), 911-945.

Kanter, R. M. (2011). How great companies think differently. Harvard Business Review.

Karaibrahimoğlu, Y. Z. (2010). Corporate social responsibility in times of financial crisis. African Journal of Business Management, 4(4), 382-389.

Kilkenny, M., Nalbarte, L., \&Besser, T. (1999).Reciprocated community support and small town-small business success. Entrepreneurship \& Regional Development, 11(3), 231-246.

Logsdon, J. M., \& Wood, D. J. (2002). Business citizenship: From domestic to global level of analysis. Business Ethics Quarterly, 12(02), 155187.

Makni, R., Francoeur, C., \&Bellavance, F. (2009). Causality between corporate social performance and financial performance: Evidence from Canadian firms. Journal of Business Ethics, 89(3), 409-422.

Miras, M. M., Escobar, B., \& Carrasco, A. (2013).The impact of the economic crisis on the environmental responsibility of the companies.business world, 17, 18.

Miura, M. N., Marcon, R., \& Sousa, M. J. B. (2011). A Crise Global e seus Impactos no Desempenho do Indíce de Sustentabilidade Empresarial-ISE e do Indíce BovespaIbovespa. XXXI ENEGEP-Encontro Nacional de Engenharia de Produção, Proceedings..., Belo Horizonte/MG, Brazil.

Meyer, J. W., \& Rowan, B. (1977). Institutionalized organizations: Formal structure as myth and ceremony. American journal of sociology, 340-363.

Neter, J., Wasserman, W., \&Kutner, M. H. (1990).Applied Linear Models, Regression, Analysis of Variance and Experimental Designs. RD Irwin, Boston, USA.
Njoroge, J. (2009). Effects of the global financial crisis on corporate social responsibility in multinational companies in Kenya. Covalence Intern Analyst Papers, available at: www. covalence. ch/docs/Kenya-Crisis. pdf accessed on, 30 .

Orlitzky, M., Schmidt, F. L., \&Rynes, S. L. (2003). Corporate social and financial performance: A meta-analysis. Organization studies, 24(3), 403441.

Pearce, J.A., II. andDoh, J.P. (2005), "The high impact of collaborative social initiatives", MIT Sloan Management Review, Vol 46 No 3, pp. 3039.

Polanyi, K. (1944). The great transformation: The political and economic origins of our time. Beacon Press.

Porter, M. E., \&Teisberg, E. O. (2006). Redefining health care: creating value-based competition on results. Harvard Business Press.

Porter, M.E. and Kramer, M.R. (2002), "The competitive advantage of corporate philanthropy", Harvard Business Review, Vol 80 No 12, pp. 5668.

Schulz, M. (2003). Pathways of relevance: Exploring inflows of knowledge into subunits of multinational corporations. Organization Science, 14(4), 440-459.

Scott, W. R. (1995). Institutions and organizations (Vol. 2). Thousand Oaks, CA: Sage. Simionescu, L., \&Dumitrescu, D. (2014).Corporate social responsibility and financial crisis. EDITORIAL BOARD, 31.

Fernández-FeijóoSouto, B. (2009). Crisis and corporate social responsibility: threat or opportunity?. International Journal of Economic Sciences and Applied Research, (1), 36-50.

Uzzi, B. (1996). The sources and consequences of embeddedness for the economic performance of organizations: The network effect. American sociological review, 674-698.

Uzzi, B. (1997). Social structure and competition Revista de Negócios, v. 21, n. 3-4, p. 25-38, July, 2016. 
in interfirm networks: The paradox of embeddedness. Administrative science quarterly, 35-67.

Wang, Q., Dou, J., \&Jia, S. (2015). A Meta-

Analytic Review of Corporate Social

Responsibility and Corporate Financial

Performance The Moderating Effect of Contextual

Factors. Business \& Society, 0007650315584317.

Yelkikalan, N., \&Köse, C. (2012).The effects of the financial crisis on corporate social responsibility. International Journal of Business and Social Science, 3(3), 292-300.

Zaheer, S. (1995).Overcoming the liability of foreignness. Academyof Management journal, 38(2), 341-363.

Revista de Negócios, v. 21, n. 3-4, p. 25-38, July, 2016. 